\title{
Trends in artisanal fisheries of Bardawil lagoon with reference to shrimp bottom trawling (kalsa)
}

\author{
El-Azab E. B. El-Bokhty ${ }^{1}$ and Attia A. El-Aiatt ${ }^{2}$ \\ 1- Fishing Gear and Methods Laboratory, National Institute of Oceanography and \\ Fisheries, Alexandria, Egypt. \\ 2- Fish Biology Laboratory, National Institute of Oceanography and Fisheries, \\ Alexandria, Egypt. \\ E-mail; elbokhty@yahoo.com
}

\section{ABSTRACT}

Bardawil lagoon is one of the most important fishing grounds in Egypt, since it is the least polluted lagoon in Egypt and in the whole Mediterranean as well as the majority of fish species are exported. Analysis of fish yields and efforts performed in Bardawil lagoon during the period 2003-2012 was done. Production trends of yearly total fish yields revealed an increasing trend with decreasing increments $\left(\mathrm{R}^{2}=71.9\right.$, $\mathrm{P}=0.018)$. The same trends were observed for both crabs $\left(\mathrm{R}^{2}=76.9, \mathrm{P}=0.003\right)$, shrimps $\left(\mathrm{R}^{2}=58.9, \mathrm{P}=0.04\right)$ and sea bream $\left(\mathrm{R}^{2}=57.7, \mathrm{P}=0.05\right)$, while that of family Mugilidae revealed increasing trends along the period of study $\left(\mathrm{R}^{2}=28.0\right)$ with insignificant relationship.

Analysis of efforts exerted by shrimp trawl net revealed that the number of hauls seems to be the controlling factor as stepwise regression between the different catches resulting from the shrimp bottom trawl net and the number of hauls had shown significant relationships except large shrimps which showed insignificant relationship.

Banning of fishing by shrimp trawl net should be superior more than further studies to develop such fishing method, as there is an alternative eco-friendly shrimp fixed traps which should be used. In addition to its destruction effect to the bottom habitats and bottom flora which acts as shelter and spawning areas for many fish species.

Keywords: Artisanal fisheries, Bardawil lagoon, shrimp bottom trawling

\section{INTRODUCTION}

The loss of habitats in relation to fisheries is increasingly becoming an important issue (ICES, 2010). As species like sole, plaice, cod, whiting etc. are bottom dwelling species, usually in close contact with the seafloor, all commercial bottom fishing for these species potentially impact the seabed. The impact of physical contact of bottom trawls affects biological communities (e.g. Kaiser et al. (2006), Schratzberger et al. (2009)) as well as the chemical (e.g. Dounas et al. (2007) and physical environment (e.g. Fonteyne (1999).

It is therefore important to monitor changes in the fish community as well as the exploited stock, to ensure the ecosystem is not damaged by the fishery. Catch, effort, discards and biological data are required to monitor the direct effects of exploitation, and fisheries-independent and environmental monitoring may also be necessary to track all ecological changes (FAO, 1998).

Vital rates in both the efforts and catch per unit efforts exerted are important for estimating the risk of extinction or decline of a fish population. Catch per-unit-effort is used in many ways. Changes in the abundance of the stock from year to year and by 
studying a time series of catch per unit effort and total landings by fleets (e.g. gear or boat category), by commercial species group, fishing area and fishing season, will help in detection of the overfishing problems. Hence, the present research was suggested to throw the light on the fish catch trends and efforts exerted on Lake Bardawil with reference to that exerted by shrimp trawling method (Kalsa), which may be helpful in fishery management of Lake Bardawil.

\section{MATERIAL AND METHOD}

Bardawil lagoon (Fig. 1) is a shallow hyper-saline lagoon with an average area of about $650 \mathrm{Km}^{2}$. It extends to about $90 \mathrm{~km}$ length with a maximum width of $22 \mathrm{~km}$, and range in depth from 0.3 to $3 \mathrm{~m}$. It occupies much of the Mediterranean coast of Sinai and separated from the sea by a sandbar that varies in width between $100 \mathrm{~m}$ and $1 \mathrm{~km}$. Bardawil was connected to the sea via one small natural inlet at its eastern extremity (Boughaz Zaranik) and two man-made inlets (Boughaz I and II). The fishing in the lagoon is seasonal starting in April and extends to the end of December. The Bardawil lagoon fisheries are operated on a small scale basis, utilizing small boats and limited technology which is comprised of trammel nets, trawl nets, shrimp and crab nets and hook and line (Mehana et al.2011).

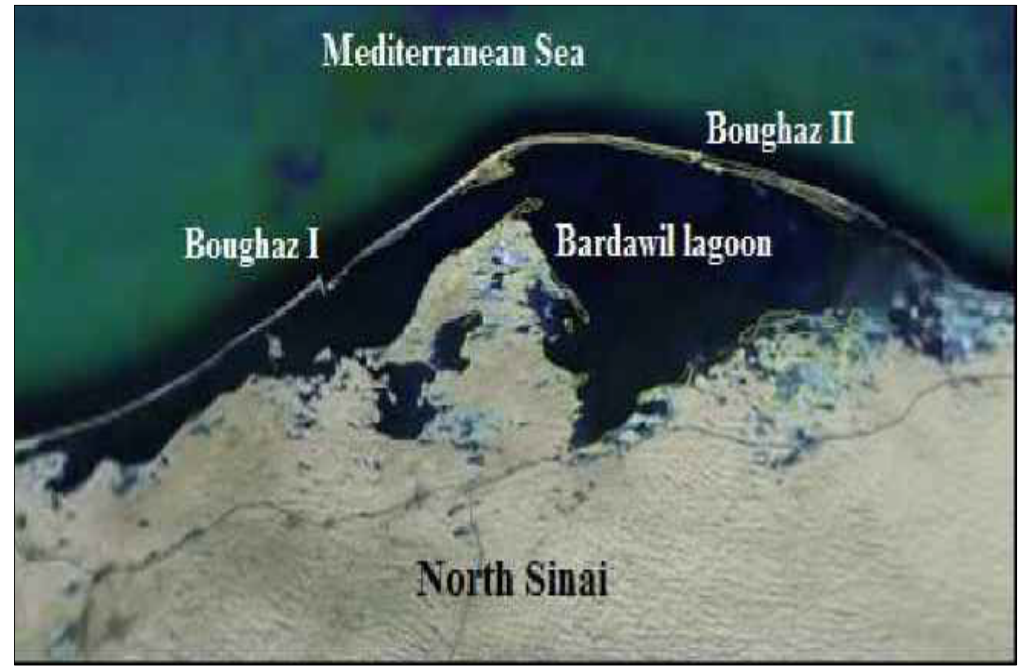

Fig. 1: Sattelite image of Bardawil lagoon

The present study is based on data obtained from fish statistical reports of the General Authority of Fish Resources Development (GAFRD, 2003-2012). Statistical analysis of time - series was performed on the total fish production and the common fish species and the rate of their changes for assessing variations in fish production of the lake.

Forty three surveys were conducted covering 400 fishing boat along Bardawil lagoon during the fishing seasons 2013 to identify the catch composition of trawl net (kalsa). Surveys covered the two months where shrimp trawling is conducted during mid-April till mid-June. Five to six surveys were carried out each week where the catch of a number of hauls was taken and transported to the laboratory where the samples were washed, sorted into small shrimp, large shrimps and crabs as target species and other small fish species as by-catch. The mean weight of each category per day per boat was estimated for each of the three codends used and then raised to the whole trawling period (60 days) and to the half number of trawlers (614 boats) to estimate the total annual weight of the lagoon. 
Trawl dimensions were measured and the catch was classified on the basis of codend mesh size of the used trawl net.

Statistical analysis was carried out using minitab-15 computer program in order to get the most suitable and best-fitting relationships between the different parameters.

\section{RESULTS AND DISCUSSION}

\section{Fish species in Bardawil lagoon}

The average catches of crabs and shrimps represented $30.36 \%$ and $25.55 \%$ of the total average catch of Bardawil lagoon respectively during the period 2003-2012. Family Mugilidae represented the third order by $24.56 \%$, seabream, sole fish and Dicentrarchus labrax represented $7.13 \%, 4.72 \%$ and $1.16 \%$ respectively and the rest $(6.52 \%)$ was of other fish species of little importance (Fig. 2).

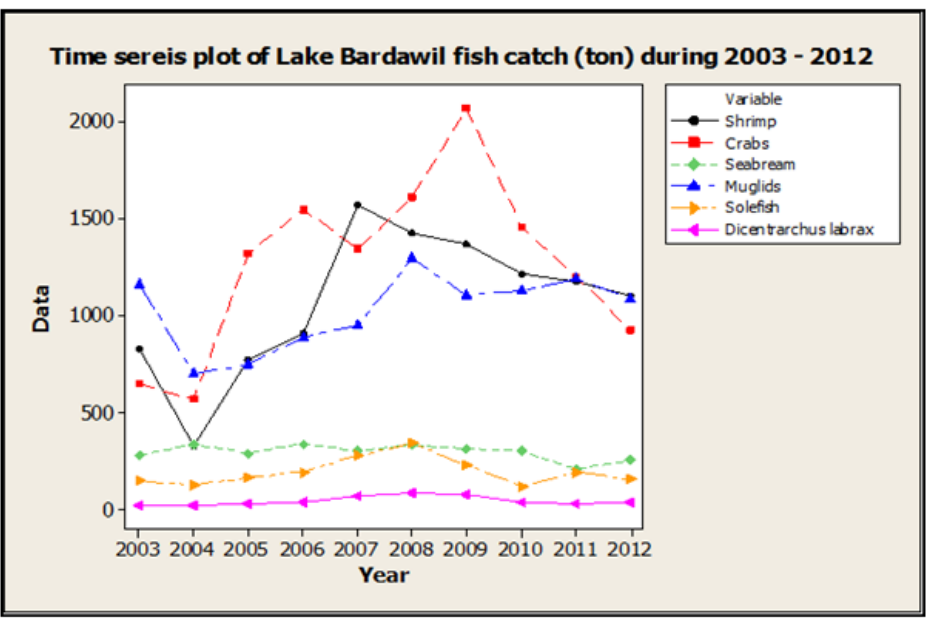

Fig. 2: Time series plot of Lake Bardawil fish catch during 2003 - 2012.

The total fish catch during the period 2003-2012 varied between a maximum of 5410 ton in 2009 and a minimum of 2227 ton in 2004 with an annual average of about 4184 ton. The relationship between the total fish catch and the successive years (Fig. 3) was found to follow the best fitted polynomial regression equation revealing a secular trend:

$$
\mathrm{Y}=1382+1076 \mathrm{X}-79.69 \mathrm{X}^{2}
$$

Where $\mathrm{Y}=$ Total catch and $\mathrm{X}=$ Time in Year

$$
\mathrm{R}^{2}=71.9 \%, \quad \mathrm{~F}=8.96, \quad \mathrm{P}=0.012
$$

From the equation (1), it can be seen that:

(1) The total fish production of Bardawil lagoon represents a proximated parabolic curve with an overall decreasing trend (- 79.69).

(2) Coefficient of determination $\left(\mathrm{R}^{2}\right)$ is about 0.72 which means that about $72 \%$ of the total fish production is connected with time and the equation was significant at $\mathrm{P}=0.012$.

(3) Although F-test (8.96) was high, the equation was significant with a relatively higher determination coefficient.

In fact this period can be divided into two different sub-periods. The first subperiod from 2003 to 2008 which can be characterized by a growing trend in the fish catch $(\mathrm{r}=+0.89)$. An increased effort exerted by fishermen caused the declined trend in fish catch in the second sub-period from 2009 to $2012(\mathrm{r}=-0.98)$. 


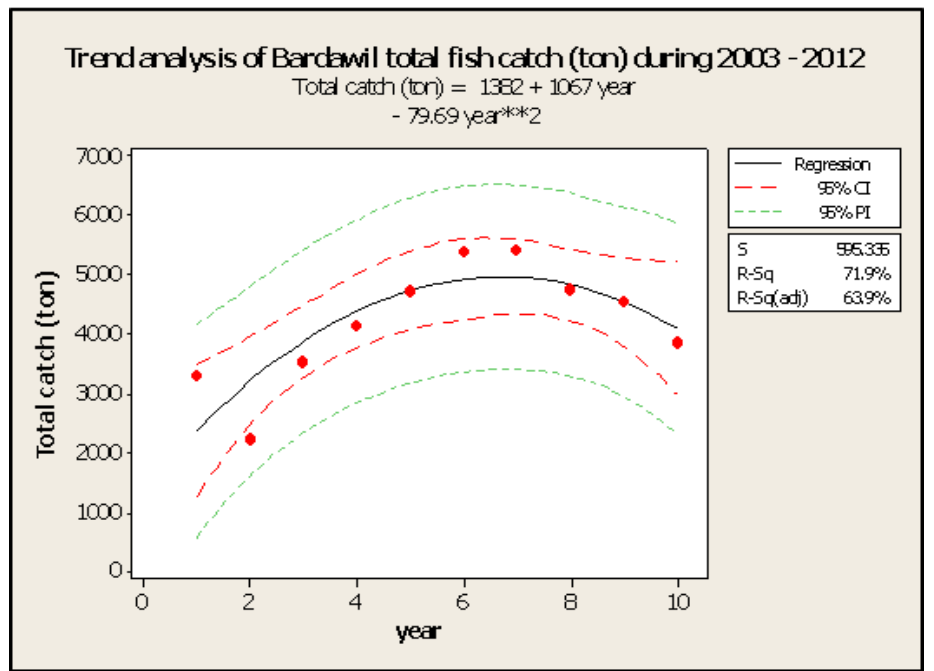

Fig. 3: Trend analysis of Bardawil total fish catch during 2003 - 2012

\section{Crab total catch of Bardawil lagoon}

The minimum catch of crabs (570 ton) was observed in 2004 and the maximum catch was 2071 ton in 2009 and then decreased to 926 ton in 2012.

The relationship between crab catch and time progression was found to follow the polynomial regression model:

$\mathrm{Y}=-80.9+575.8 \mathrm{X}-47.17 \mathrm{X}^{2}$

where $\mathrm{Y}=$ yield of crabs in tons, $\mathrm{X}=$ Time index in Year

$\mathrm{R}^{2}=76.9, \mathrm{~F}=11.67, \mathrm{P}=0.006$

From the equation (2) and Fig. (4), it can be seen that,

(1) The crab catch approximated the parabolic curve with a decreasing trend with progression in time.

(2) Coefficient of determination is about 76.9

(3) All the recorded crab catches were belonging to $95 \%$ confidence interval area except that of the maximum production (2071 ton during 2009) was inside the prediction interval area and the relation is significant at $\mathrm{P}=0.006$.

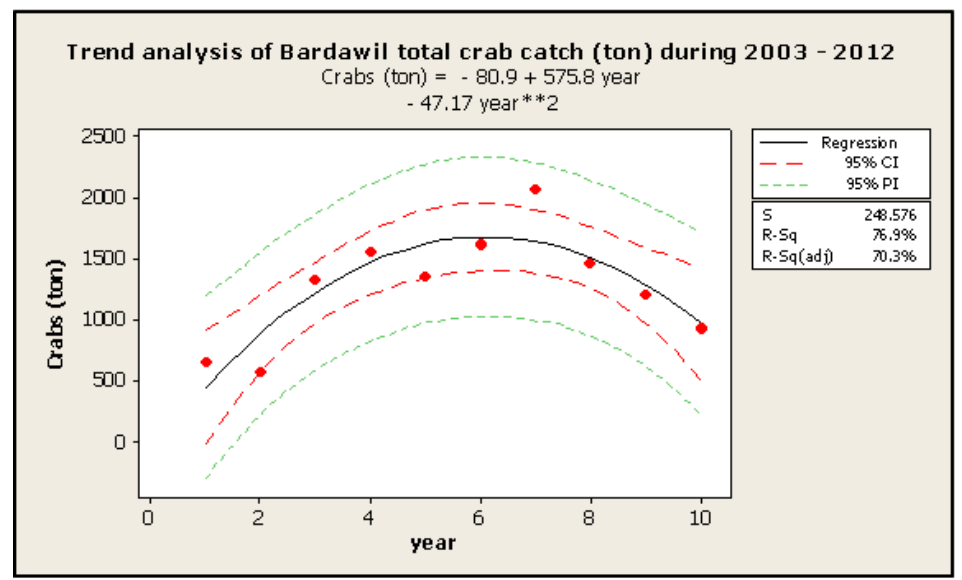

Fig. 4: Trend analysis of crabs caught off Lake Bardawil during 2003-2012

\section{Total shrimp catch of Bardawil lagoon}

The relationship between shrimp catch and time progression was found to follow the polynomial regression model:

$\mathrm{Y}=156.5+330.9 \mathrm{X}-23.55 \mathrm{X}^{2}$

where $\mathrm{Y}=$ yield of total shrimps in tons, $\mathrm{X}=$ Time index in Year

$\mathrm{R}^{2}=58.9, \mathrm{~F}=5.03, \mathrm{P}=0.044$ 
From the equation (3) and Fig. (5), it can be seen that,

(1) The total shrimp catch approximated the parabolic curve with a slight decreasing trend with progression in time.

(2) Coefficient of determination is about 58.9

(3) All the recorded values of total shrimps were belonging to $95 \%$ confidence interval area except that of the minimum production (329 ton during 2004) and that of maximum (1569 ton during 2007) were inside the prediction interval area and the relation is significant at $\mathrm{P}=0.044$.

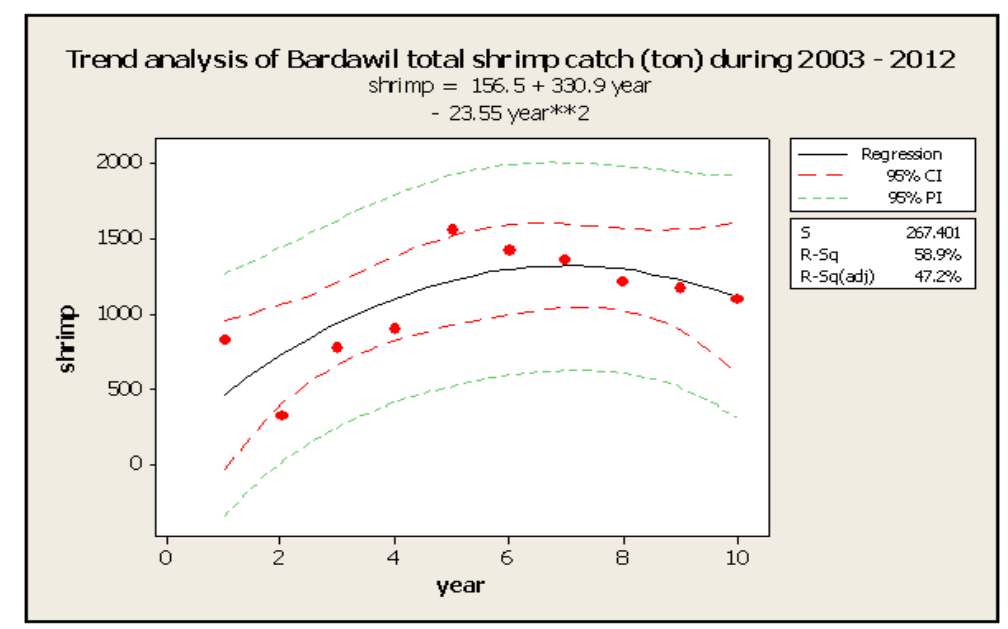

Fig. 5: Trend analysis of total shrimp catch of Lake Bardawil during 2003-2012.

\section{Total seabream catch of Bardawil lagoon}

The relationship between seabream catch and time progression was found to follow the polynomial regression model (Fig. 6):

$\mathrm{Y}=271.3+25.57 \mathrm{X}-2.951 \mathrm{X}^{2}$

where $\mathrm{Y}=$ yield of total seabream in tons, $\mathrm{X}=$ Time index in Year

$\mathrm{R}^{2}=57.7, \mathrm{~F}=4.77, \mathrm{P}=0.049$

From the equation (4) and Fig. (6), it can be seen that,

(1) The total seabream catch approximated the parabolic curve with a sharp decreasing trend with progression in time.

(2) Coefficient of determination is about 57.7.

(3) All the recorded values were belonging to $95 \%$ confidence interval area except that of the minimum production (212 ton during 2011) was inside the prediction interval area and the relation is significant at $\mathrm{P}=0.049$.

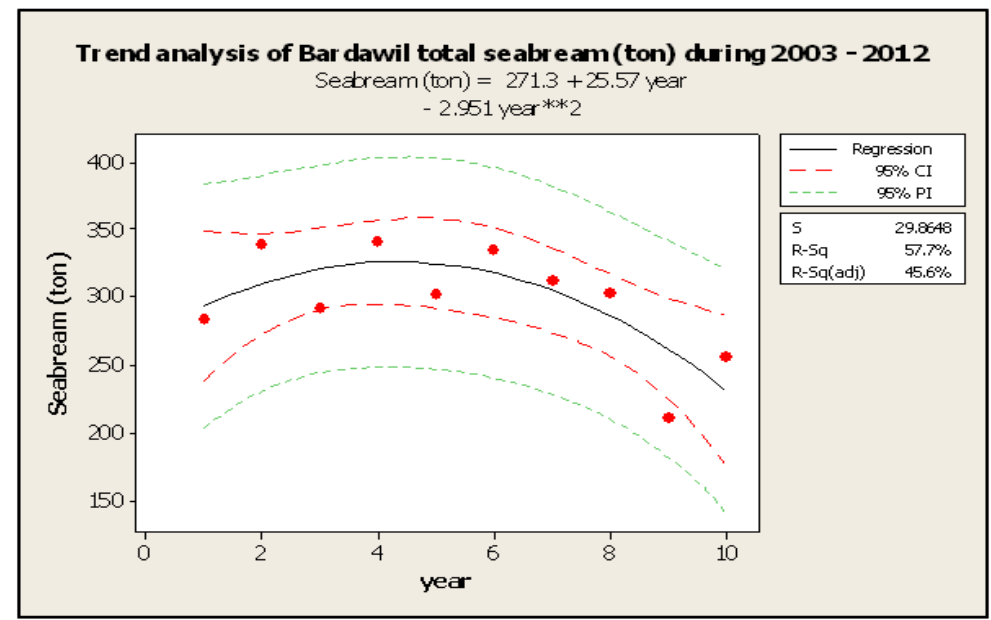

Fig. 6: Trend analysis of total seabream catch of lake Bardawil during $2003-2012$. 


\section{Total mugilids catch of Bardawil lagoon}

The relationship between muglids catch and time progression was found to follow the logarithmic polynomial regression model (Fig. 7):

$\log Y=3.023-0.4843 \log X+0.5726 \log X^{2}$

where $\mathrm{Y}=$ yield of total muglid fish in tons, $\mathrm{X}=$ Time index in Year

$$
\mathrm{R}^{2}=55.2, \mathrm{~F}=4.32, \mathrm{P}=0.06
$$

From the equation (5) and Fig. (7), it can be seen that,

(1) The total muglid catch approximated the parabolic curve with an increasing trend with progression in time.

(2) Coefficient of determination is about 58.9

(3) All the recorded values were belonging to $95 \%$ confidence interval area except that of the maximum production (1298 ton during 2008) was inside the prediction interval area and the relation is significant at $\mathrm{P}=0.06$.

(4) The quadratic polynomial equation was not significant.

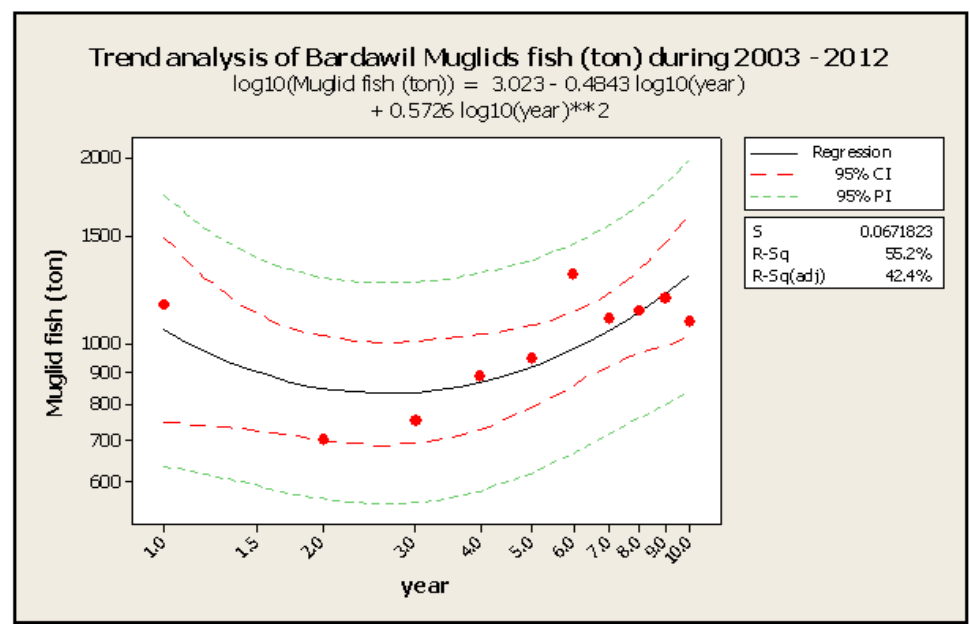

Fig. 7: Trend analysis of total muglids catch of Lake Bardawil during $2003-2012$.

\section{Total sole catch of Bardawil lagoon}

The relationship between sole catch and time progression was found to follow the logarithmic cubic polynomial regression model (Fig. 8):

$\log ($ Sole $($ ton $))=2.178-1.485 \log X+5.177 \log X^{2}$

$$
\text { - } 3.726 \log X^{3}
$$

where $\mathrm{Y}=$ yield of total sole fish in tons, $\mathrm{X}=$ Time index in Year

$$
\mathrm{R}^{2}=57.2, \mathrm{~F}=5.2, \mathrm{P}=0.064
$$

From the equation (6) and Fig. (8), it can be seen that,

(1) The total sole catch approximated the parabolic curve with an increasing trend during most of the period the decreases with progression in time.

(2) Coefficient of determination is about 57.2.

(3) All the recorded values were belonging to $95 \%$ confidence interval area except that of the minimum production (123 ton during 2010) was inside the prediction interval area and the relation is significant at $\mathrm{P}=0.064$.

(4) The quadratic polynomial equation was not significant. 


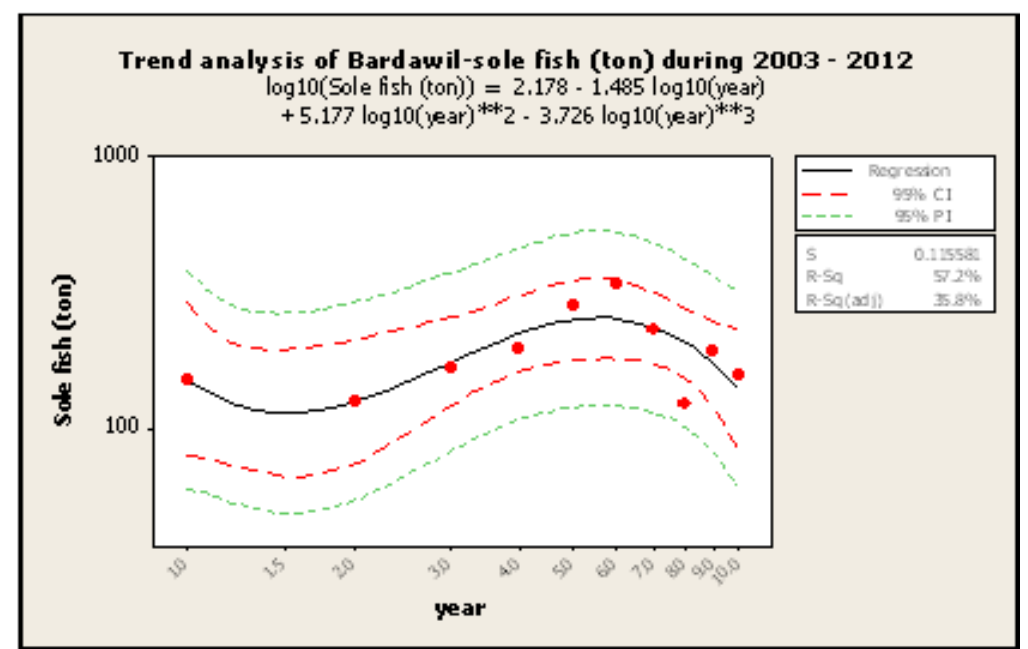

Fig. 8: Trend analysis of total sole catch of Lake Bardawil during 2003 - 2012.

\section{Total Dicentrarchus labrax catch of Bardawil lagoon}

The relationship between Dicentrarchus labrax catch and time progression was found to follow the polynomial regression model :

$$
\mathrm{Y}=-9.47+25.05 \mathrm{X}-2.076 \mathrm{X}^{2}
$$

where $\mathrm{Y}=$ yield of total Dicentrarchus labrax, $\mathrm{X}=$ Time index in Year

$$
\mathrm{R}^{2}=55.8, \mathrm{~F}=4.41, \mathrm{P}=0.058
$$

From the equation (7) and Fig. (9) it can be seen that,

(1) The total Dicentrarchus labrax catch approximated the parabolic curve with an increasing trend with progression in time.

(2) Coefficient of determination is about 55.8.

(3) All the recorded values were belonging to $95 \%$ confidence interval area except that of the maximum production (90 ton during 2008) was inside the prediction interval area and the relation is significant at $\mathrm{P}=0.058$.

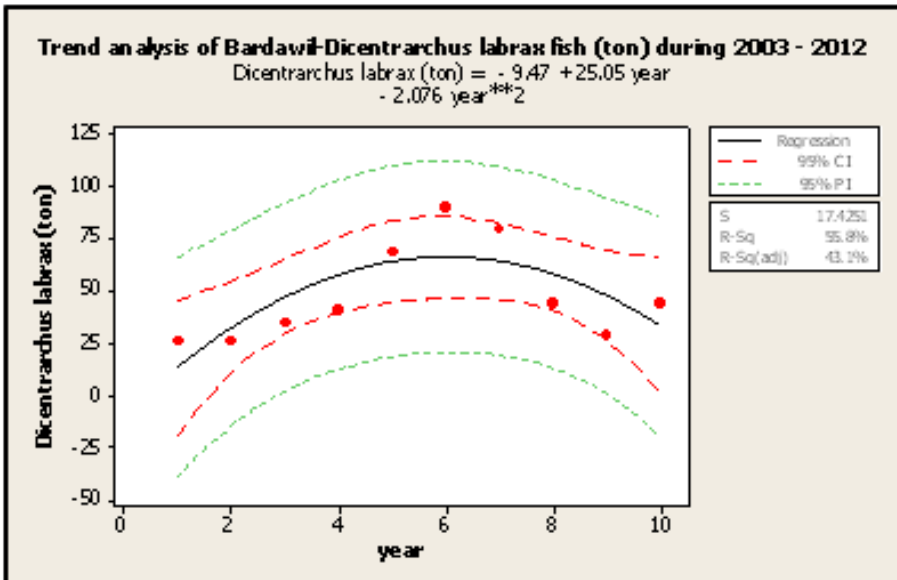

Fig. 9: Trend analysis of total Dicentrarchus labrax catch of lake Bardawil durıng $2003-2012$

\section{Description of bottom trawl (kalsa) fishery}

Shrimp bottom trawling which locally named as kalsa was introduced to Bardawil lagoon by 1995. It was operating at the beginning of the fishing season (April, May, June and July), but now this period was restricted to only two months, April and May (Mehana et al.2011).

The trawl net (kalsa) is used mainly for fishing crustaceans especially shrimp. It consists of two wings and a bag; the length of each wing is about $10 \mathrm{~m}$ (it changes from place to place, according to personal judgment) and its height is about $2 \mathrm{~m}$. The 
head rope of the wing is fitted with floats to keep the bag open; the distance between floats is about $25 \mathrm{~cm}$, while the footrope of the wing is fitted with sinkers of about 25 $\mathrm{cm}$ apart which keep the bag creeping on the bottom (Mehana et al.2011).

The bag net is about $14.1 \mathrm{~m}$ in length and $8 \mathrm{~mm}$ mesh size. The mouth of the bag net has a radius of about $12 \mathrm{~m}$. A total of 1228 fishing boats were used the trawl nets, each net is dragged by two boats, the fishermen throw the net in water, then the boats move to deeper water where the bag is dragged and finally, the two wings and the bag are pulled to one of the boats to collect the catch (Mehana et al.2011).

The present study revealed that the majority of the catch is represented mainly of shrimps (small and large combined) by about $38 \%$, crab by about $33 \%$ and bycatch by about $27 \%$. The major portion of total shrimps (about $27 \%$ ) was small shrimp and the remained portion was large shrimps (about $11.9 \%$ ) (Table 1). The results coincide with those obtained by Mehana et al. (2011). Large shrimps were represented by two species mainly of Penaeus semisulcatus and P. japonicus. Bycatch, which represents small juveniles of high value fish species like seabream fish and soles beside other low valued fish, represented also a higher proportion of bottom trawl catch (about $27 \%$ ).

Table 1: Average catch of bottom trawl net (Kalsa), Bardawil lagoon, 2013.

\begin{tabular}{|l|l|l|l|l|l|}
\hline Av. Catch & No. of Hauls & $\begin{array}{l}\text { Small } \\
\text { Shrimp }\end{array}$ & $\begin{array}{l}\text { Large } \\
\text { Shrimp }\end{array}$ & Crabs & By-Catch \\
\hline Boat/day (kg) & 17 & 28.47 & 12.45 & 35.58 & 28.56 \\
\hline $\begin{array}{l}\text { Total catch/ } \\
\text { Season (Ton) }\end{array}$ & & 908.834 & 397.615 & 1136.043 & 911.989 \\
\hline
\end{tabular}

The major species in Kalsa (trawl) by-catches were gilthead seabream juveniles, soles juveniles, groupers, glass eel, Terapon puta, sardinella aurita, Atherina, and others like shells, gastropods, jelly fish, squilla, small crabs and small sized non targeted fish. It was shown by Mehana et al.(2011) that an averaged catch of this bycatch reached $66 \mathrm{~kg}$ per day while, in this study, the by-catch reached $28.6 \mathrm{~kg}$ per day. This difference may return to the differences in fish density during the period of collection.

It was shown that (Tables $2,3 \& 4$ ) the majority of bottom trawl fishing boats (about 58.14 \%) use trawls of codends \# 80-85 mesh/ $50 \mathrm{~cm}$ net, $27.9 \%$ of boats use codends less than 80 mesh / $50 \mathrm{~cm}$ net and the remained portion $(13.9 \%)$ use nets larger than 85 mesh $/ 50 \mathrm{~cm}$.

These small differences in codends' mesh sizes seems to have no effect on the species or even the size composition of the catches of bottom trawl nets due to the diamond nature of meshes used in codends which tends to close under the towing force and the fish loads inside the codend, therefore tests were used to show the correlations between the different catches and the number of hauls carried out by the fishing boat (Table 5).

Based on analysis of $95 \%$ CIs of means (as a part of One way-ANOVA), It was shown that catch of small shrimps was highly correlated to the number of hauls for the codend $80-85 / 50 \mathrm{~cm}\left(\mathrm{R}^{2}=73.28, \mathrm{~F}=6.86, \mathrm{P}<0.005\right)$ and for the three codends combined, the relation was as following;

Small shrimps $(\mathrm{Kg})=-13.2+2.52$ No. of hauls $\left(\mathrm{R}^{2}=58.6 \%, \mathrm{~F}=58.01\right.$ and $\mathrm{P}<0.005$ ) (Fig. 10). 
Table 2: Fish catch of shrimp trawl net (codend \# 80-85/50 cm), Lake Bardawil, 2013.

\begin{tabular}{|c|c|c|c|c|c|c|c|c|c|c|}
\hline \multirow[b]{2}{*}{ Obs. } & \multirow{2}{*}{$\begin{array}{l}\text { Av. No. of } \\
\text { boats / day }\end{array}$} & \multirow{2}{*}{$\begin{array}{l}\text { Av. No. of } \\
\text { hauls /day }\end{array}$} & \multicolumn{4}{|c|}{ Av. Catch / haul / day (kg) } & \multicolumn{4}{|c|}{ Raised total catch / day (kg) } \\
\hline & & & $\begin{array}{l}\text { Large } \\
\text { Shrimp }\end{array}$ & Crabs & $\begin{array}{l}\text { small } \\
\text { shrimp }\end{array}$ & By-catch & $\begin{array}{l}\text { Large } \\
\text { shrimps }\end{array}$ & Crabs & $\begin{array}{l}\text { small } \\
\text { shrimp }\end{array}$ & By-catch \\
\hline 1 & 7 & 18 & 0.5 & 2 & 2 & 2 & 9 & 36 & 36 & 36 \\
\hline 2 & 3 & 20 & 0.5 & 2 & 1.5 & 1.5 & 10 & 40 & 30 & 30 \\
\hline 3 & 11 & 21 & 0.25 & 2 & 4 & 2 & 5.25 & 42 & 84 & 42 \\
\hline 4 & 6 & 20 & 0.25 & 3 & 3 & 2 & 5 & 60 & 60 & 40 \\
\hline 5 & 8 & 17 & 0.5 & 1.5 & 0.5 & 1 & 8.5 & 25.5 & 8.5 & 17 \\
\hline 6 & 11 & 15 & 0.5 & 2 & 0.5 & 1 & 7.5 & 30 & 7.5 & 15 \\
\hline 7 & 12 & 18 & 0.5 & 2 & 3 & 2 & 9 & 36 & 54 & 36 \\
\hline 8 & 12 & 19 & 0.5 & 2 & 1 & 1 & 9.5 & 38 & 19 & 19 \\
\hline 9 & 7 & 13 & 0.5 & 2 & 1 & 1 & 6.5 & 26 & 13 & 13 \\
\hline 10 & 8 & 17 & 0.5 & 1.5 & 1.5 & 3 & 8.5 & 25.5 & 25.5 & 51 \\
\hline 11 & 12 & 18 & 0.25 & 2 & 3 & 3 & 4.5 & 36 & 54 & 54 \\
\hline 12 & 11 & 20 & 0.25 & 2 & 3 & 3 & 5 & 40 & 60 & 60 \\
\hline 13 & 14 & 20 & 0.5 & 1 & 2 & 2.5 & 10 & 20 & 40 & 50 \\
\hline 14 & 8 & 17 & 0.5 & 1.5 & 2 & 1.5 & 8.5 & 25.5 & 34 & 25.5 \\
\hline 15 & 13 & 20 & 0.5 & 3 & 2 & 3 & 10 & 60 & 40 & 60 \\
\hline 16 & 15 & 40 & 0.5 & 1 & 2 & 2.5 & 20 & 40 & 80 & 100 \\
\hline 17 & 11 & 45 & 0.25 & 1 & 2 & 2 & 11.25 & 45 & 90 & 90 \\
\hline 18 & 14 & 45 & 0.25 & 2 & 2 & 1 & 11.25 & 90 & 90 & 45 \\
\hline 19 & 11 & 14 & 0.5 & 2.5 & 2 & 1 & 7 & 35 & 28 & 14 \\
\hline 20 & 9 & 14 & 0.5 & 2.5 & 1.5 & 1.5 & 7 & 35 & 21 & 21 \\
\hline 21 & 11 & 21 & 0.5 & 1 & 1.5 & 2 & 10.5 & 21 & 31.5 & 42 \\
\hline 22 & 12 & 18 & 0.25 & 1.5 & 2 & 3 & 4.5 & 27 & 36 & 54 \\
\hline 23 & 9 & 20 & 0.5 & 3 & 1.5 & 2 & 10 & 60 & 30 & 40 \\
\hline 24 & 7 & 12 & 1 & 3 & 1 & 1 & 12 & 36 & 12 & 12 \\
\hline 25 & 9 & 17 & 0.5 & 2 & 2 & 1.5 & 8.5 & 34 & 34 & 25.5 \\
\hline Average $(\mathrm{kg})$ & & 21 & 0.45 & 1.96 & 1.9 & 1.88 & 8.75 & 38.54 & 40.72 & 39.68 \\
\hline $\begin{array}{c}\text { Seasonal } \\
\text { Total } \backslash \text { boat }(\mathrm{kg})\end{array}$ & & 1092 & & & & & 491.4 & 2140.3 & 2074.8 & 2053 \\
\hline $\begin{array}{llr}\text { Total } & \backslash 357 \\
\text { boat } & \text { Iseason } \\
\text { (ton) } & \end{array}$ & & & & & & & 175.4 & 764.1 & 740.7 & 732.9 \\
\hline
\end{tabular}

Table 3: Fish catch \& fishing effort of shrimp trawl net (codend $<\# 80 / 50 \mathrm{~cm}$ ), Lake Bardawil, 2013.

\begin{tabular}{|c|c|c|c|c|c|c|c|c|c|c|}
\hline \multirow{2}{*}{ Obs. } & \multirow{2}{*}{$\begin{array}{l}\text { Av. No. } \\
\text { of boats } \\
\text { / day }\end{array}$} & \multirow{2}{*}{$\begin{array}{l}\text { Av. No. } \\
\text { of hauls } \\
\text { /day }\end{array}$} & \multicolumn{4}{|c|}{ Av. Catch / haul / day (kg) } & \multicolumn{4}{|c|}{ Raised total catch / boat / day (kg) } \\
\hline & & & $\begin{array}{l}\begin{array}{l}\text { Large } \\
\text { shrimp }\end{array} \\
\end{array}$ & Crabs & $\begin{array}{l}\begin{array}{l}\text { small } \\
\text { shrimp }\end{array} \\
\end{array}$ & By-catch & $\begin{array}{l}\text { Large } \\
\text { shrimp }\end{array}$ & Crabs & $\begin{array}{l}\text { small } \\
\text { shrimp }\end{array}$ & By-catch \\
\hline 1 & 3 & 15 & 0.5 & 3 & 1 & 2 & 7.5 & 45 & 15 & 30 \\
\hline 2 & 9 & 14 & 1 & 2 & 1 & 0.25 & 14 & 28 & 14 & 3.5 \\
\hline 3 & 2 & 14 & 2 & 2 & 0.5 & 0 & 28 & 28 & 7 & 0 \\
\hline 4 & 8 & 18 & 0.5 & 4 & 0.5 & 0.5 & 9 & 72 & 9 & 9 \\
\hline 5 & 3 & 16 & 3 & 1.5 & 0.5 & 0.5 & 48 & 24 & 8 & 8 \\
\hline 6 & 9 & 12 & 2 & 2 & 1.5 & 0.25 & 24 & 24 & 18 & 3 \\
\hline 7 & 3 & 10 & 1 & 2 & 0 & 1 & 10 & 20 & 0 & 10 \\
\hline 8 & 7 & 17 & 1.5 & 3 & 1 & 0.25 & 25.5 & 51 & 17 & 4.25 \\
\hline 9 & 5 & 14 & 0.5 & 2.5 & 2 & 1 & 7 & 35 & 28 & 14 \\
\hline 10 & 7 & 14 & 1 & 1.5 & 0 & 0 & 14 & 21 & 0 & 0 \\
\hline 11 & 2 & 12 & 2 & 1 & 0 & 0.5 & 24 & 12 & 0 & 6 \\
\hline 12 & 8 & 16 & 0.25 & 3 & 1 & 0.5 & 4 & 48 & 16 & 8 \\
\hline Average & & 14 & 1.27 & 2.29 & 0.75 & 0.56 & 17.78 & 32 & 10.5 & 7.8 \\
\hline $\begin{array}{l}\text { Seasonal } \\
\text { Total/boat }\end{array}$ & & 728 & & & & & 925.6 & 1664 & 546 & 405.6 \\
\hline $\begin{array}{l}\text { Total } \backslash 171 \\
\text { boat } \mid \text { season }\end{array}$ & & & & & & & 158.1 ton & 284.5 ton & 93.4 ton & 69.4 ton \\
\hline
\end{tabular}


Table 4: Fish catch \& fishing effort of shrimp trawl net (codend > \# 80/50 cm), Lake Bardawil, 2013.

\begin{tabular}{|c|c|c|c|c|c|c|c|c|c|c|}
\hline \multirow{2}{*}{ Obs. } & \multirow{2}{*}{$\begin{array}{l}\text { Av. } \\
\text { No. of } \\
\text { boats / } \\
\text { day }\end{array}$} & \multirow{2}{*}{$\begin{array}{l}\text { Av. } \\
\text { No. of } \\
\text { hauls } \\
\text { /day }\end{array}$} & \multicolumn{4}{|c|}{ Av. Catch / haul / day (kg) } & \multicolumn{4}{|c|}{ Raised total catch / day (kg) } \\
\hline & & & $\begin{array}{l}\text { Large } \\
\text { shrimp }\end{array}$ & $\begin{array}{l}\text { Crab } \\
\text { s }\end{array}$ & $\begin{array}{l}\text { small } \\
\text { shrim } \\
\text { p }\end{array}$ & $\begin{array}{l}\text { By- } \\
\text { catch }\end{array}$ & $\begin{array}{l}\text { Large } \\
\text { shrimp }\end{array}$ & Crabs & $\begin{array}{l}\text { small } \\
\text { shrimp }\end{array}$ & By-catch \\
\hline 1 & 16 & 16 & 0.5 & 3 & 3 & 3 & 8 & 48 & 48 & 48 \\
\hline 2 & 9 & 18 & 0.5 & 1.5 & 2.5 & 3 & 9 & 27 & 45 & 54 \\
\hline 3 & 13 & 18 & 0.25 & 3 & 2 & 2.5 & 4.5 & 54 & 36 & 45 \\
\hline 4 & 20 & 20 & 0.25 & 2 & 2.5 & 3 & 5 & 40 & 50 & 60 \\
\hline 5 & 12 & 18 & 0.5 & 3 & 3.5 & 2.5 & 9 & 54 & 63 & 45 \\
\hline 6 & 13 & 18 & 0.5 & 2 & 3 & 3 & 9 & 36 & 54 & 54 \\
\hline Average & 14 & 18 & 0.42 & 2.42 & 2.75 & 2.83 & 7.42 & 43.17 & 49.33 & 51 \\
\hline $\begin{array}{l}\text { Seasonal } \\
\text { Total booat }\end{array}$ & & 936 & & & & & 385.8 & 2244.8 & 2565.2 & 2652 \\
\hline $\begin{array}{l}\text { Total } \mid 85 \\
\text { boat/season }\end{array}$ & & & & & & & $\begin{array}{l}32.796 \\
\text { ton }\end{array}$ & $\begin{array}{l}190.808 \\
\text { ton }\end{array}$ & $\begin{array}{l}218.04 \\
\text { ton }\end{array}$ & $\begin{array}{l}225.420 \\
\text { ton }\end{array}$ \\
\hline
\end{tabular}

Table 5: Stepwise regression of fish catches by common codend $(80-85 \backslash 50 \mathrm{~cm})$ shrimp trawl net (Kalsa) at Bardawil Lake during 2013

\begin{tabular}{|c|c|c|c|c|c|}
\hline Compared items & No. of hauls & $\begin{array}{l}\text { Small } \\
\text { Shrimp }\end{array}$ & Large shrimp & Crabs & By-catch fish \\
\hline No. of hauls & n. a. & $\begin{array}{l}\mathrm{N}=25 \\
\mathrm{~T}=6.37 \\
\mathrm{P}=0.000 * \\
\mathrm{R}^{2}=63.82\end{array}$ & $\begin{array}{l}\mathrm{N}=25 \\
\mathrm{~T}=3.22 \\
\mathrm{P}=0.004 \% \\
\mathrm{R}^{2}=31.06\end{array}$ & $\begin{array}{l}\mathrm{N}=25 \\
\mathrm{~T}=3.2 \\
\mathrm{P}=0.004 * \\
\mathrm{R}^{2}=30.86\end{array}$ & $\begin{array}{l}\mathrm{N}=25 \\
\mathrm{~T}=5.05 \\
\mathrm{P}=0.000 * \\
\mathrm{R}^{2}=52.57\end{array}$ \\
\hline Small shrimp & & n. a. & $\begin{array}{l}\mathrm{N}=25 \\
\mathrm{~T}=0.97 \\
\mathrm{P}=0.344 \\
\mathrm{R}^{2}=3.09\end{array}$ & $\begin{array}{l}\mathrm{N}=25 \\
\mathrm{~T}=5.33 \\
\mathrm{P}=0.000 * \\
\mathrm{R}^{2}=55.22\end{array}$ & $\begin{array}{l}\mathrm{N}=25 \\
\mathrm{~T}=3.10 \\
\mathrm{P}=0.005 * \\
\mathrm{R}^{2}=29.5\end{array}$ \\
\hline Large shrimp & & & n. a. & $\begin{array}{l}\mathrm{N}=25 \\
\mathrm{~T}=2.14 \\
\mathrm{P}=0.043 * \\
\mathrm{R}^{2}=16.64\end{array}$ & $\begin{array}{l}\mathrm{N}=25 \\
\mathrm{~T}=0.72 \\
\mathrm{P}=0.478 \\
\mathrm{R}^{2}=2.21\end{array}$ \\
\hline Crabs & & & & n. a. & $\begin{array}{l}\mathrm{N}=25 \\
\mathrm{~T}=1.14 \\
\mathrm{P}=0.267 \\
\mathrm{R}^{2}=5.33\end{array}$ \\
\hline
\end{tabular}

* The relation is significant at $\mathrm{P} \leq 0.05$,

$\mathrm{N}=$ Number of observations, $\mathrm{T}=\mathrm{t}-$ test, $\mathrm{P}-$ value, and $\mathrm{n} . \mathrm{a} .=$ not available

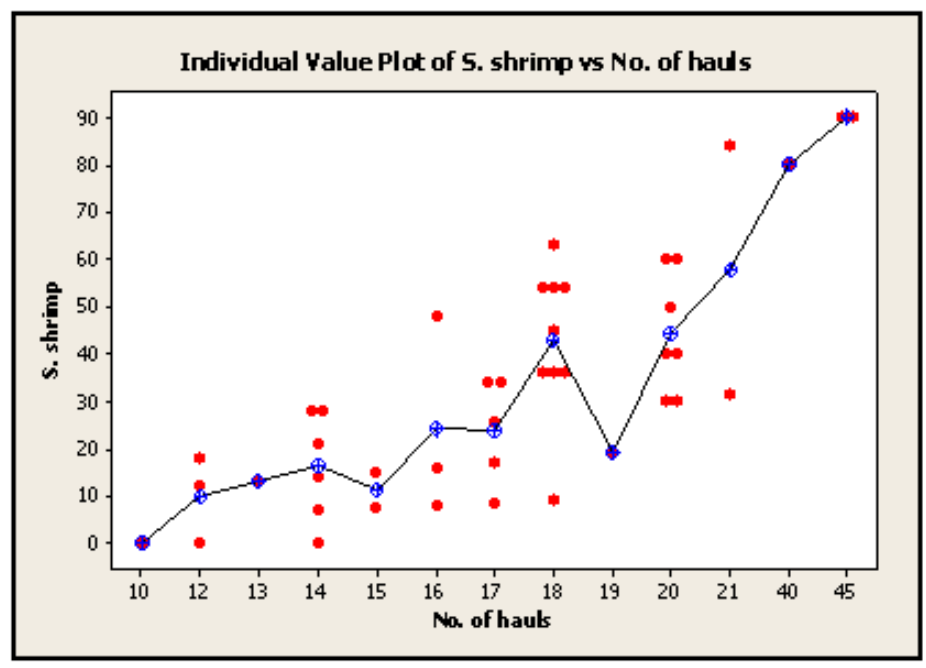

Fig. 10: Individual value plot of small shrimps versus number of hauls 
Also, crabs catch was significantly correlated with the number of hauls $\left(\mathrm{R}^{2}=\right.$ 77.4, $\mathrm{P}=0.001$ ) although the coefficient of determination was low for the whole data combined $\left(\mathrm{R}^{2}=24.8\right)$ (Fig. 11) and the relation was; Crabs $(\mathrm{Kg})=18.8+1.03$ No. of hauls.

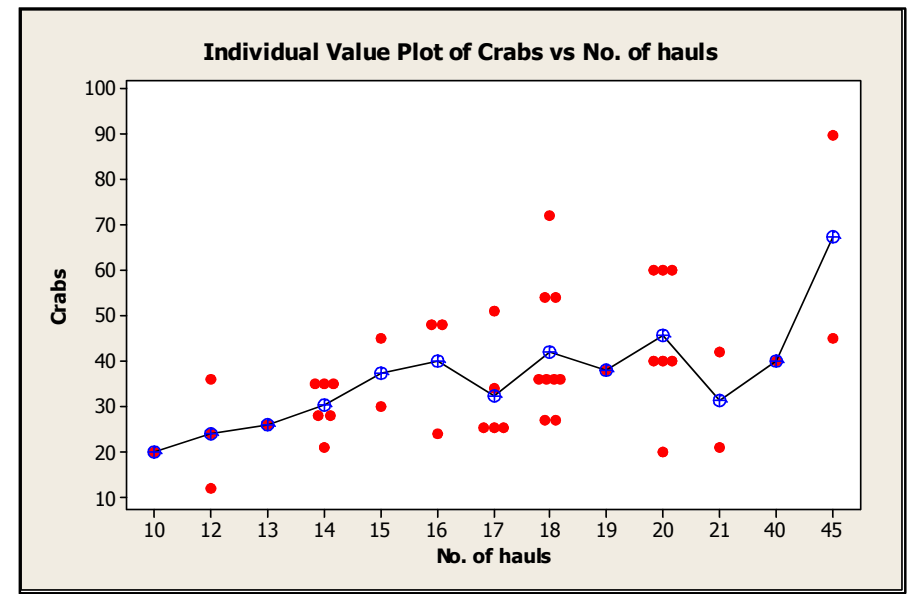

Fig. 11: Individual value plot of crabs versus number of hauls

By-catches were also positively correlated with the number of hauls (Fig. 12) and the relation was;

By-catch $(\mathrm{kg})=-8.89+2.22$ No. of hauls $\left(\mathrm{R}^{2}=48, \mathrm{P}<0.005\right)$.

Correlations among the different catches of shrimp bottom trawl revealed either insignificant relationships or significant with low coefficient of determinations except that small shrimps with by-catch $\left(\mathrm{R}^{2}=67.3, \mathrm{P}<0.005\right)$ and the relation was;

Small shrimp $(\mathrm{Kg})=6.37+0.841$ Bycatch.

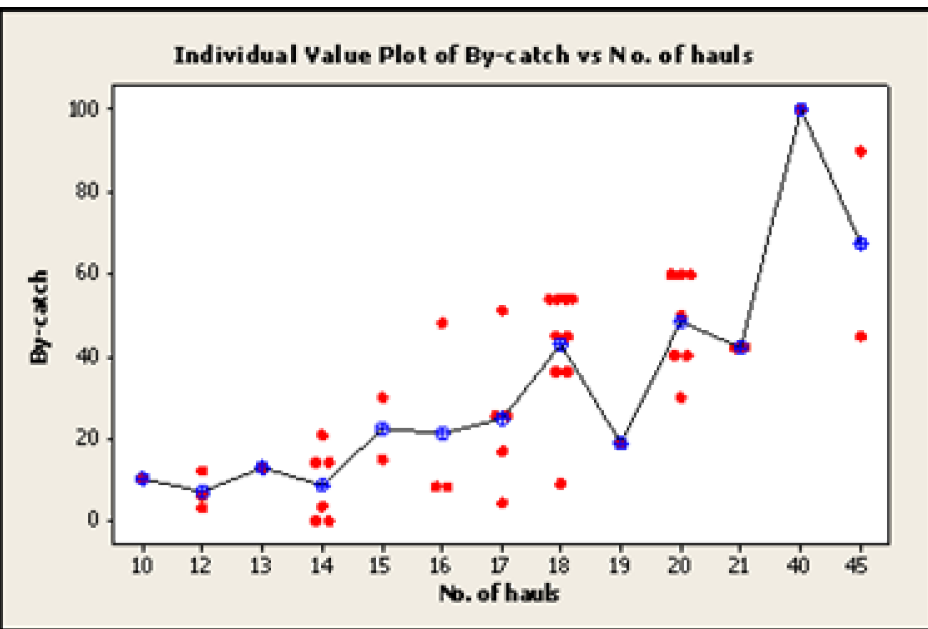

Fig. 12: Individual value plot of total bycatch versus number of hauls

The whole relations as shown as similarity dendrogram at Fig. (13) revealed higher correlations between small shrimps and by-catches with the number of hauls than large shrimps and crabs. However, the largely unknown temporal and spatial dynamics of target and non-target species as well as of fishermen makes it difficult to find a link between species composition and fishing effort. 


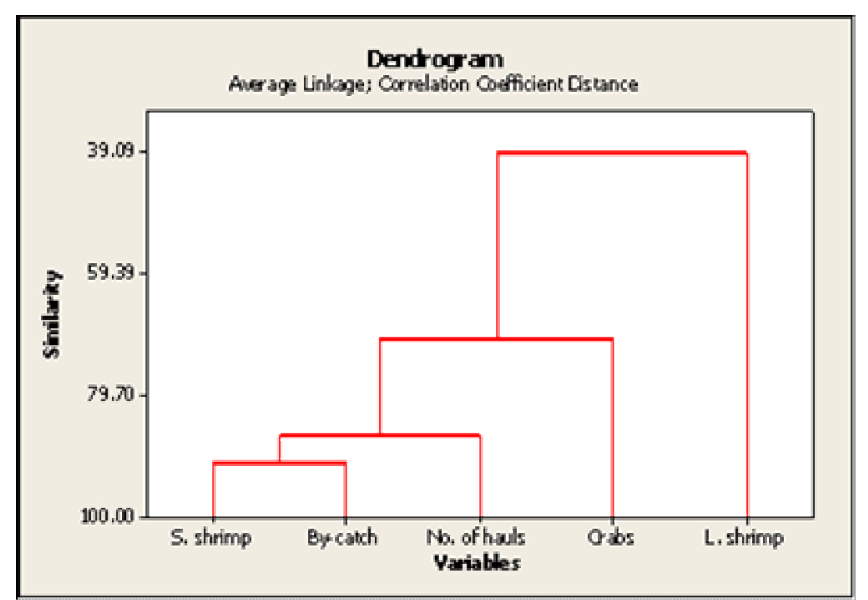

Fig. 13: Correlations between different catches of bottom trawling shown as similarity dendrogram.

\section{CONCLUSION}

Preservation of the bottom ecosystem is superior to any further studies to develop shrimp bottom trawling method as its production mainly depends on the number of hauls as revealed from the present study (i.e. more destruction to the bottom floor). Such studies should be directed towards the fixed shrimp trap nets to select the more appropriate and suitable meshes for shrimps prevailing in the lake while shrimp bottom trawling, beside its additional fry overfishing, should be banned off.

\section{REFERENCES}

Dounas, C., Davies, I., Triantafyllou, G., Koulouri, P., Petihakis, G., Arvanitidis, C., Sourlatzis, G., Eleftheriou, A. (2007). Large-scale impacts of bottom trawling on shelf primary productivity. Continental Shelf Research, 27: 2198-2210.

FAO, (1998). Guidelines for the routine collection of capture fishery data. FAO Fisheries Technical Paper 382.

Fonteyne, R. (1999). In situ experiments of seabed disturbance by beam trawls. ILVO-Fisheries, Oostende, Belgium, p. 14.

GAFRD (2003 - 2012). The General Authority of Fish Resources Development, Year Book of Fishery Statistics, Cairo, Egypt.

ICES (2010). Report of the Working Group on the Ecosystem Effects of Fishing Activities (WGECO). In press. Copenhagen, Denmark., 205p.

Kaiser, M. J., Clarke, K. R., Hinz, H., Austen, M. C. V. S., Somerfield, P. J., Karakakkis, I. (2006). Global analysis of response and recovery of benthic biota to fishing. . Mar. Ecol. Progr. Ser., 1-14.

Mehanna, S. F. ; Attia El-Aiatt and Mohamed Salem (2011). An investigation of the impacts of shrimp bottom trawling on the Bardawil lagoon fisheries, Egypt. Egypt. J. Aquat. Biol. \& Fish., 15(3):415 - 424.

Schratzberger, M., Lampadariou, N., Somerfield, P., Vandepitte, L., Vanden Berghe, E. (2009). The impact of seabed disturbance on nematode communities: linking field and laboratory observations. Marine Biology, 156: 709-724.

Welcomme, R. L.; Ian G.; Cowx, David Coates, Christophe Béné, Simon FungeSmith, Ashley Halls, and Kai Lorenzen (2010). Inland capture fisheries. Philos Trans R Soc Lond B Biol Sci. 2010 September 27; 365(1554): 2881-2896. 


\section{ARABIC SUMMARY}

اتجاهات المصايد التقليديه فى بحيرة البردويل مع الإشارة الى شباك جر الجمبرى القاعيه (الكلسه)

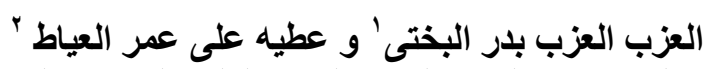

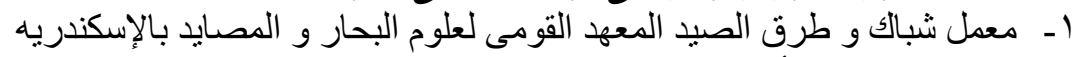
r - معمل بيولوجيا الأسماك المعهد القومى لعلوم البحار و المصايد بالإسكندريه

تعتبر بحيرة البردويل من أهم مصايد مصر حيث يصدر معظم انتاجها للخارج و انها تعتبر البحيرة

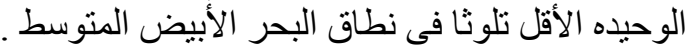

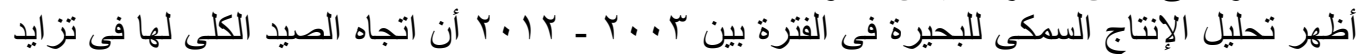

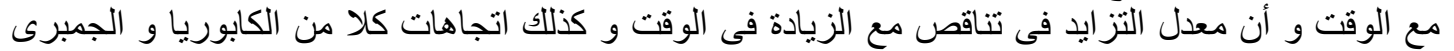

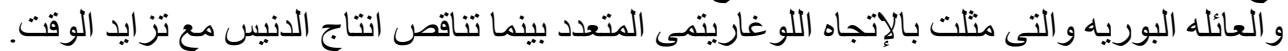

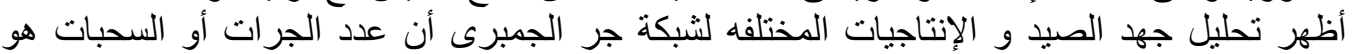

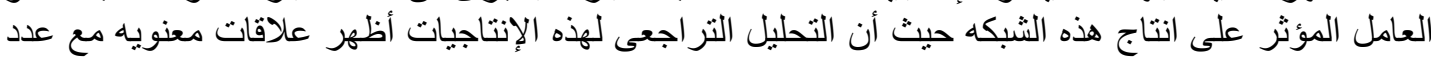

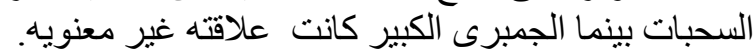

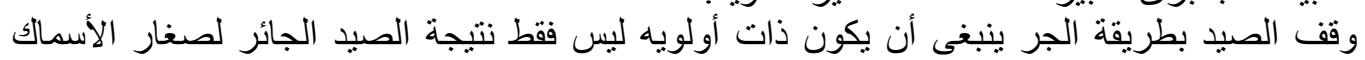

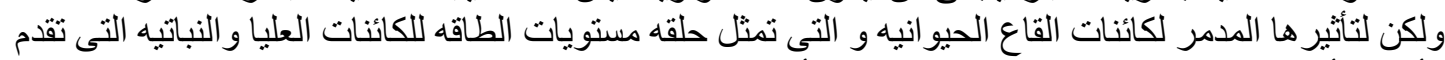

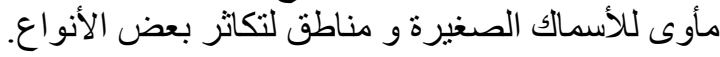

